\title{
Green synthesis of silver nanoparticles and evaluation of their anti-bacterial activities: use of Aloe barbadensis miller and Ocimum tenuiflorum leaf extracts
}

https://doi.org/10.1515/nanofab-2020-0102

Received Oct 17, 2021; accepted Nov 11, 2021
Abstract: The presence of various phytochemicals makes the leaf extract-based green synthesis advantageous to other conventional methods, as it facilitates the production of non-toxic by-product. In the present study, leaf extracts from two different plants: Aloe barbadensis miller and Ocimum tenuiflorum, were used to synthesise Ag nanoparticles. The absorbance at $419-432 \mathrm{~nm}$ from UV-visible spectroscopy indicates the formation of $\mathrm{Ag}$ in the synthesised samples. The effect of precursors' concentration on the stability, size and shape of the synthesised samples has also been investigated at constant heating temperature, stirring time, and the $\mathrm{pH}$ of the solution. The TEM results showed that all the synthesised samples of nanoparticles demonstrated stability with a size range of 7-70 and 9-48 nm with Aloe barbadensis miller and Ocimum tenuiflorum leaf extracts, respectively. The formation of smaller Ag nanoparticles due to utilisation of different precursor concentration and leaf extracts was also explained. The synthesised samples' anti-bacterial activity was examined against the pathogens, Bacillus subtilis, Staphylococcus aureus, and Escherichia coli. In general, the green synthesis approach established a prospective for developing highly stable Ag nanoparticles with rigid particle shape/size distribution from different leaf extracts for the development of better anti-bacterial agents.

Keywords: Aloe barbadensis miller; Anti-bacterial agent; Bacillus subtilis; Green synthesis; Ocimum tenuiflorum; Silver nanoparticles

\footnotetext{
*Corresponding Author: Kuldeep Kumar: Department of Chemistry, Career Point University Hamirpur (HP) 176041, India; Center for Nano-Science and Technology, Career Point University Hamirpur (HP) 176041, India; Email: kuldeep.sharma.753@gmail.com Saurabh Sharma: Department of Chemistry, Career Point University Hamirpur (HP) 176041, India; Center for Nano-Science and Technology, Career Point University Hamirpur (HP) 176041, India
}

\section{Introduction}

Plant-based green synthesis of metal oxide nanoparticles (NPs) are gaining prominence due to its simplicity, commercial scalability, and versatility in using imperishable and lower-risk value-added components. At present, nanoscience and nanotechnology is one of the fastestgrowing and promising fields, which requires considerable attention to develop environmentally benevolent methods of synthesis of NPs that avoid the use of deadly chemicals [15]. In this context, the deployment of green chemistry reduces the use or generation of toxic chemicals during the synthesis processes [6]. Consequently, the research interest in fabricating metal NPs through biological approaches, especially leaf extracts, is developing rapidly. This is because of simple experimentation, environmental friendliness, reproducibility, and cost-effectiveness of biological routes compared to physical and chemical-based methods [7]. Thus, there is a boost in demand for green nanotechnology $[8,9]$. Generally, a variety of bioactive phytochemicals present in micro and macro organisms like algae, bacteria, fungi, and plants can be used for the green synthesis of NPs [10-12]. However, in green nanotechnology, the plant leaf extracts have been extensively used compared to microorganism approaches because plants are safe to handle, widely available, and possess a variety of phytochemicals that act as reducing/stabilising agents during the synthesis of NPs [13-15].

Undoubtedly, various novel NPs like $\mathrm{ZnO}, \mathrm{CuO}, \mathrm{Au}$, Ag, Fe, Pd [16, 17] and so on, have been synthesised by using green technology. However, the silver and gold NPs attracted tremendous interest due to extensive applicability in various areas such as drug delivery systems, electronics, energy-efficient systems, and in the field biomedical science

Naveen Thakur: Department of Physics, Career Point University Hamirpur (HP) 176041, India; Center for Nano-Science and Technology, Career Point University Hamirpur (HP) 176041, India 
as promising antimicrobial, wound healing, bone repairing, and anticancer agents [18-21]. Recently, NPs are explored as nanomedicines for early diagnosis and treatment of many deadly diseases like cancer [22, 23]. Nanomedicines are very effective in the treatment of the cancer cells like Osteosarcoma (a type of bone cancer) [24], Retinoblastoma (an ophthalmological cancer) [25], etc. In addition, NPs are also playing their role as a safer drug carrier in the effective drug delivery systems for the drugs like crosin [26] and deferasirox [27].

In this context, recently, various plants like Camellia sinensis [28], Foeniculum vulgare [29], Green and Black tea leaves [30], Imperata cylindrical [31], Oak fruit hull (Jaft) [32], Origanum vulgare [33], Phoenix dactylifera [34], Emblica Officinalis [35], Forsythia suspens [36], Impatiens balsamina [37], Jack fruit [38], Lantana camara [37], Nigella sativa [39], Phyllanthus emblica [40], Salvia spinose [41], Achillea millefolium [42], Apricot and Black Currant Pomace [43], Astragalus tribuloides Delile [44], Berry extract of Sea Buckthorn [3], Capparis zeylanica [45], Codonopsis pilosula [46], Congolese plant species (Brillantaisia patula, Crossopteryx febrifuga, and Senna siamea) [47], Cucumis prophetarum [48], Lysiloma acapulcensis [49], Lysimachia foenum-graecum Hanse [50], Plantago [51], Capsicum annuum L. [52], and Tragopogon Collinus [53] are taken into consideration to synthesise nano silver-based materials. Recently, Ahmed and Mustafa [54] have critically reviewed the potentiality and diversity of silver NPs' biological activities mediated by the phyto-constituents of several traditional medicinal plants. They concluded that more studies are required to focus on the effect of pure secondary metabolites that may control the morphology and applications, particularly the silver NPs' biological activities.

Despite this all, the confined availability and high cost of the majority of the medicinal plants compel the researchers to think about the use of commonly available and cost effective plants. Toward this, the use of medicinal plants that are locally or easily available like Aloe barbadensis miller (aloe-vera) and Ocimum tenuiflorum (tulsi) is significant. Many studies have been reported on the biosynthesis of silver NPs [41, 55-65]. However, maximum of the reported work has been performed at a minimal precursor concentration. In addition, the effect of the change in the precursor concentration on the shape and size of synthesised Ag NPs is also not much explored. Nowadays, the frightening phenomenon of occurrence of drug-resistant bacteria is a major concern of the universal healthcare system. Hence, silver NPs represent the novel biocompatible nanostructured materials for unconventional antimicrobial applications [66]. This is due to their inherent broad bactericidal effects demonstrated against both Gram-positive and
Gram-negative bacteria. Silver nano-structures are one of the most used metallic NPs in contemporary anti-bacterial applications [67]. In their anti-bacterial action, Ag NPs penetrate the cell and produce a drastic disturbance regarding structural damage, proper cell function, and ultimately results into cell death [68].

Therefore, in this present work, plant leaf extracts from Aloe barbadensis miller and Ocimum tenuiflorum were used as feedstock for the synthesis of Ag NPs. The leaves of Aloe barbadensis miller typically consist of active constituents: flavonoids, vitamins, sugars, saponins, amino acids, lignins, alkaloids, steroidal lactones, and tannin $[69,70]$. On the other hand, Ocimum tenuiflorum or tulsi (commonly known in India) is native to the old world tropics and contains several phytochemical compounds such as phenols, amino acids, flavonoids, etc. in large quantities [71]. The choice of these two plants was motivated by the presence of high flavonoid contents, as flavonoids are reported to be essential for bio-synthesis of required NPs [71, 72]. Moreover, extensive characterisations of the synthesised samples using ultraviolet-visible (UV-visible) spectroscopy, X-ray diffraction (XRD) spectroscopy, energy dispersive X-ray spectroscopy (EDS), and scanning electron microscopy (SEM) and transmission electron microscopy (TEM) were also carried out to investigate the impact of synthesis conditions on the yield, the morphology, and stability of the NPs. Further, the possible application of the synthesised Ag NPs in anti-bacterial field has also been explored.

\section{Material and Methods}

\subsection{Materials}

Silver nitrate $\left(\mathrm{AgNO}_{3}\right)$ and potassium hydroxide $(\mathrm{KOH})$ were obtained from the Merck Pvt. Ltd. and were used without any further purification. The distilled water (DW) with a $\mathrm{pH}$ of $6.8-7.0$ and a conductivity of $2-3 \times 10^{-6} \mathrm{~s} \cdot \mathrm{cm}^{-1}$ (at $298.15 \mathrm{~K}$ ) was used as a medium in all the experiments. The human pathogens, Bacillus subtilis (MTCC 441), Staphylococcus aureus (MTCC 737), and Escherichia coli (MTCC 739) were procured from the CSIR-IMTECH, Chandigarh in the freeze-dried ampoule. Aloe barbadensis miller and Ocimum tenuiflorum plant leaves were collected from the nearby region of Career Point University Hamirpur (HP) India. 


\subsection{Methods}

\section{Preparation of the Aloe barbadensis miller or Ocimum tenuiflorum plant leaf extract}

Fresh leaves were collected and thoroughly washed under the tap water to remove any dust or lose material. The washed leaves were further rinsed with distilled water forremoval of impurities if any. The leaves were then dried to remove excess water and exactly 25 gm of dry leaves of Aloe barbadensis miller or 10 gm leaves of Ocimum tenuiflorum were chopped and crushed well by using mortar and pestle. Further, a well-minced leaves were boiled for about $15 \mathrm{~min}$ utes in $100 \mathrm{ml}$ of distilled water in each case. After boiling, the hot extract solution was cooled and filtered by using the Whatman No.1 filter paper. The so-obtained plant leaf extract was stored in the refrigerator for further use in the biosynthesis of Ag NPs.

\subsection{Synthesis of the Silver nanoparticles}

The stock aqueous solutions $\left(5,10\right.$, and $\left.50 \mathrm{mmol} \cdot \mathrm{kg}^{-1}\right)$ of the precursor silver nitrate $\left(\mathrm{AgNO}_{3}\right)$ were prepared in the distilled water. Then the prepared known concentration solution was taken in a flat bottom flask placed in the oil bath. The temperature of the solution was maintained at $70 \pm 1^{\circ} \mathrm{C}$. Then $20 \mathrm{ml}$ Aloe barbadensis miller or Ocimum tenuiflorum plant leaf extract as prepared above was added dropwise at a rate of approximately $5 \mathrm{ml} / \mathrm{min}$ with constant magnetic stirring. After about 15 minutes of adding Aloe barbadensis miller leaf extract, the $\mathrm{pH}$ of the reaction mixture was maintained at 11.5 with the addition of freshly prepared 0.2 $\mathrm{mol} \cdot \mathrm{kg}^{-1} \mathrm{KOH}$ solution. Initially, the change in color of the solution from colourless to redish brown and appearance of the dark black color precipitates confirm the formation of Ag NPs. The reaction mixture was allowed to reflux at $70 \pm 1^{\circ} \mathrm{C}$ under constant stirring condition for $4 \mathrm{hrs}$. After refluxing, black color precipitates were allowed to settle down at room temperature. The so-obtained nanosamples were washed 3-4 times with distilled water followed by the washing with ethanol. Finally, the material was dried at $55-60^{\circ} \mathrm{C}$ in a hot air oven. Similarly, the Ag NPs were also synthesised at 10 and $50 \mathrm{mmol} \cdot \mathrm{kg}^{-1}$ of precursor $\mathrm{AgNO}_{3}$.

\subsection{Characterisation of the silver nanoparticles}

The synthesised materials have been confirmed with the UV-Visible, XRD, SEM, TEM, and EDS spectral analysis. The
Cary 100 Bio UV-Visible instrument, which is a doublebeam spectrophotometer capable of acquiring data in the spectral range from 190 to $900 \mathrm{~nm}$ has been employed to carry out the spectral studies. The Panalytical Empyrean XRS-45 kV, XRD instrument has been used to examine the crystallinity and phase identification of the samples. Further, the morphology and shape/size of the synthesised NPs were examined by using the Carl-Zeiss Ultra 55 field emission-scanning electron microscope and JEOL JEM 2100F-200 kV transmission electron microscope. However, the elemental detection analysis of the synthesised NPs has been carried out by using the EDS attached with the SEM micrograph.

\subsection{Anti-bacterial activity of silver nanoparticles}

The anti-bacterial potential of so synthesised silver oxide NPs has been tested against the pathogens, Bacillus subtilis, Staphylococcus aureus, and Escherichia coli by using the agar well diffusion method [73]. The National Committee for Clinical Laboratory Standards (NCCLS) and Clinical and Laboratory Standards Institute (CLSI) protocols were followed during the experiments to calculate the zone of inhibition and Minimum Inhibitory Concentration (MIC)/ Minimum Bactericidal Concentration (MBC) values, respectively. The MIC and MBC values were measured by employing the method as given in our previous study on the metal oxide NPs [74].

\section{Results and Discussion}

\subsection{UV-Visible Spectroscopy}

A confirmatory and optical analysis of the prepared samples has been executed by using the UV-Visible spectrophotometer. The UV-Visible spectra of Ag NPs synthesised by using Aloe barbadensis miller and Ocimum tenuiflorum leaf extracts at 5,10 , and $50 \mathrm{mmol} \cdot \mathrm{kg}^{-1}$ of $\mathrm{AgNO}_{3}$ as precursor exhibit the characteristic absorbance peaks in the range of 419-432 nm (Figure 1). It has been reported in the literature that the Ag NPs generally show absorption band in the range 380-470 nm depending upon the size and morphology of material $[75,76]$. Further, the band gap $\left(E_{g}\right)$ values of so-obtained Ag NPs, are calculated by using equation 1 , and are tabulated in Table 1.

$$
E_{g}=\frac{h c}{\lambda_{\max }}=\frac{1240}{\lambda_{\max }}
$$




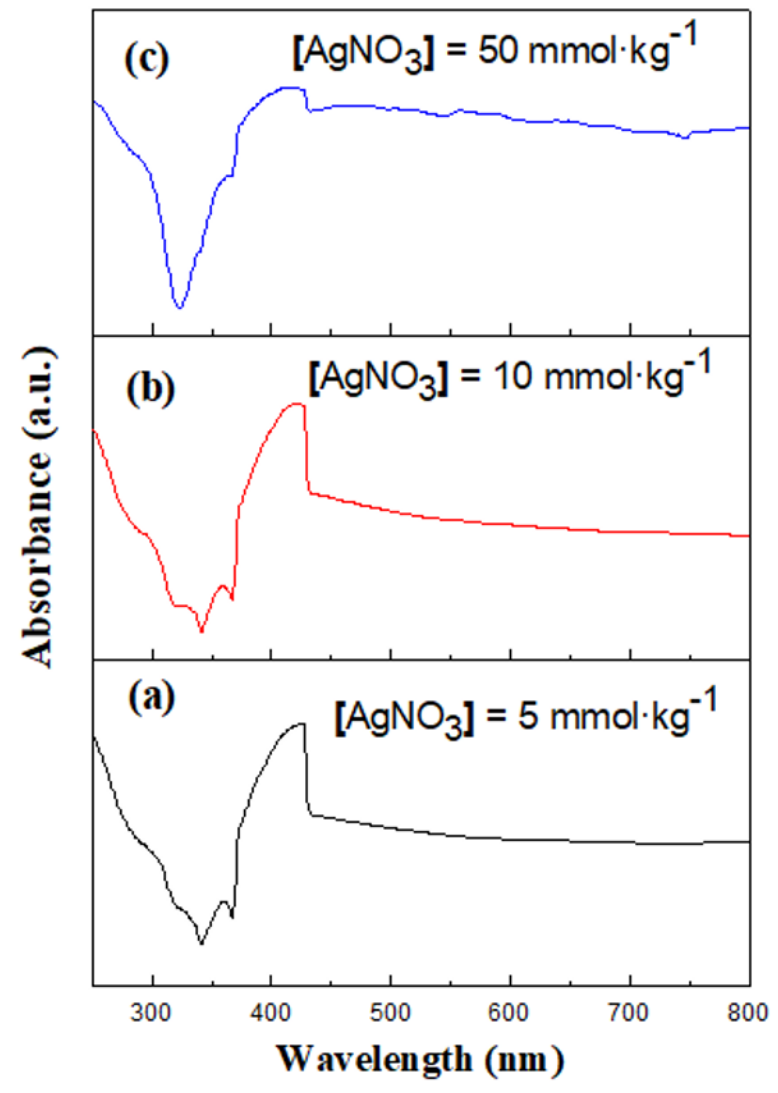

(A)

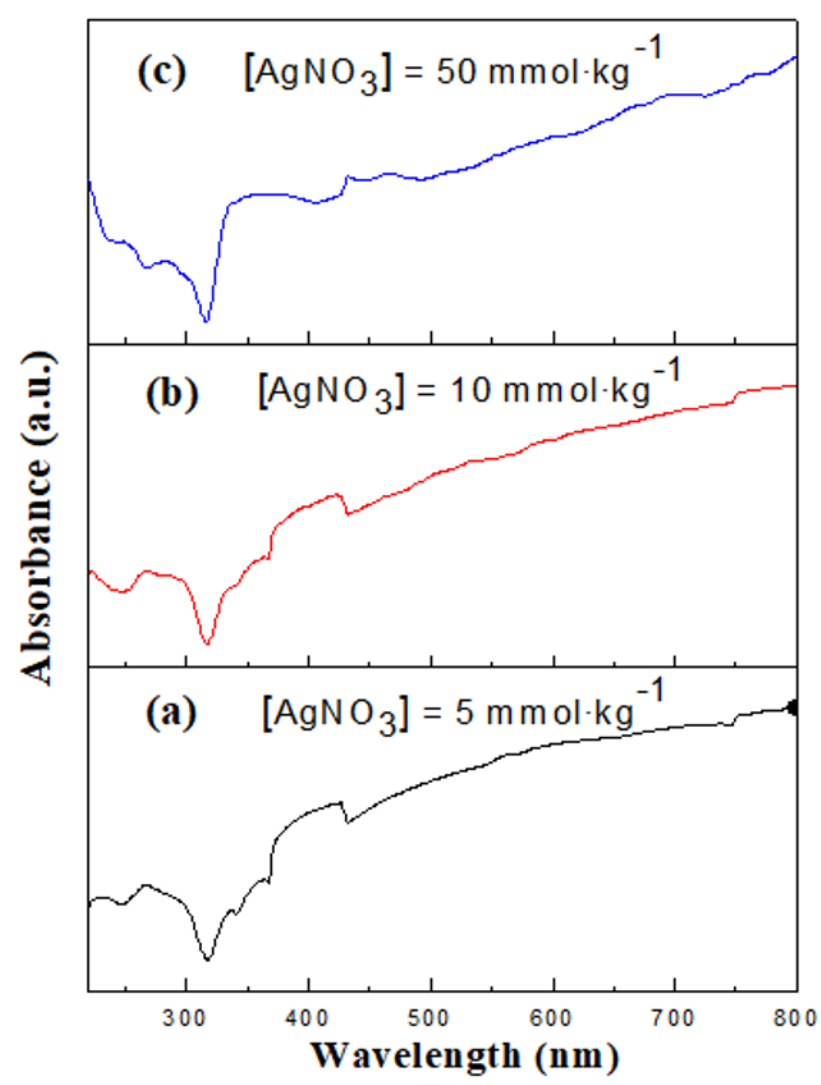

(B)

Figure 1: UV-Visible spectra of Ag NPs synthesised by using (A) Aloe barbadensis miller and (B) Ocimum tenuiflorum leaf extracts at different concentrations of the precursor $\mathrm{AgNO}_{3}$ (a-c)

Table 1: $\lambda_{\max }$ and $E_{g}$ values calculated for Ag NPs synthesized at different concentrations of $\mathrm{AgNO}_{3}$ by using Aloe barbadensis miller and Ocimum tenuiflorum leaf extracts

\begin{tabular}{cccc}
\hline Leaf Extract & $\begin{array}{c}{\left[\mathrm{AgNO}_{3}\right]} \\
\left(\mathrm{mmol} \cdot \mathrm{kg}^{-1}\right)\end{array}$ & $\begin{array}{c}\lambda_{\max } \\
(\mathrm{nm})\end{array}$ & $\begin{array}{c}E_{g} \\
(\mathrm{eV})\end{array}$ \\
\hline Aloe barbadensis & 5 & 427 & 2.904 \\
miller & 10 & 427 & 2.904 \\
& 50 & 419 & 2.959 \\
\hline Ocimum & 5 & 427 & 2.904 \\
tenuiflorum & 10 & 427 & 2.904 \\
& 50 & 432 & 2.877 \\
\hline
\end{tabular}

The change in the $\lambda_{\max }$ and $E_{g}$ values with precursors' concentration suggests the formation of Ag NPs with variable shape/size. It is also observed that such type of change in shape/size with $\lambda_{\max } / E_{g}$ values, ultimately, affecting the antibacterial activity of the synthesised samples, as discussed in sub-section anti-bacterial activity.

\subsection{XRD Analysis}

The XRD spectral analysis of each of the prepared samples represents the number of patterns as delineated in Figure 2A-B. The patterns observed at $2 \theta \approx 38.3,44.4,64.6$, and 77.5 degree could be indexed to (111), (200), (220), and (311) planes, respectively, of fcc confirms the formation of Ag NPs (JCPDS file No. 89-3722) [77, 78]. In addition to these peaks, some extra peaks at $2 \theta=29.4,33.5,46.1,55.9$, and 66.7 degree have also been obtained for the samples synthesised at $50 \mathrm{mmol} \cdot \mathrm{kg}^{-1}$ of $\mathrm{AgNO}_{3}$. These extra peaks in the patterns represent the oxide phase of silver crystal structure. Thus, XRD concluded the synthesis of pure Ag NPs at the 5 and $10 \mathrm{mmol} \cdot \mathrm{kg}^{-1}$ of $\mathrm{AgNO}_{3}$, whereas on increasing the concentration upto $50 \mathrm{mmol} \cdot \mathrm{kg}^{-1}$, the AgO NPs have also been formed. The peaks assigned to AgO crystalline phase can be equated with the XRD patterns given by Yang et al. (JCPDS file no 43-1038) [79]. The crystallite size (D) and inter-planer spacing (d) calculated by using the DebyeScherrer equations 2 and 3, respectively. The equations 4 and 5 given below have also been used for the determina- 


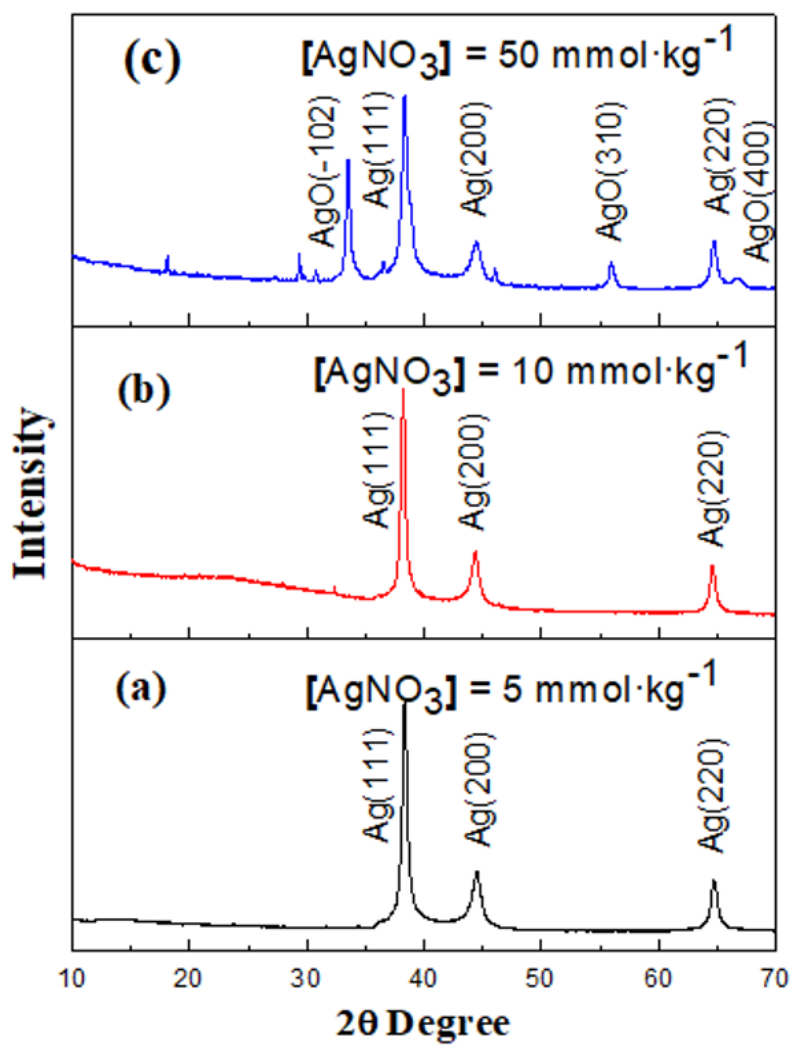

(A)

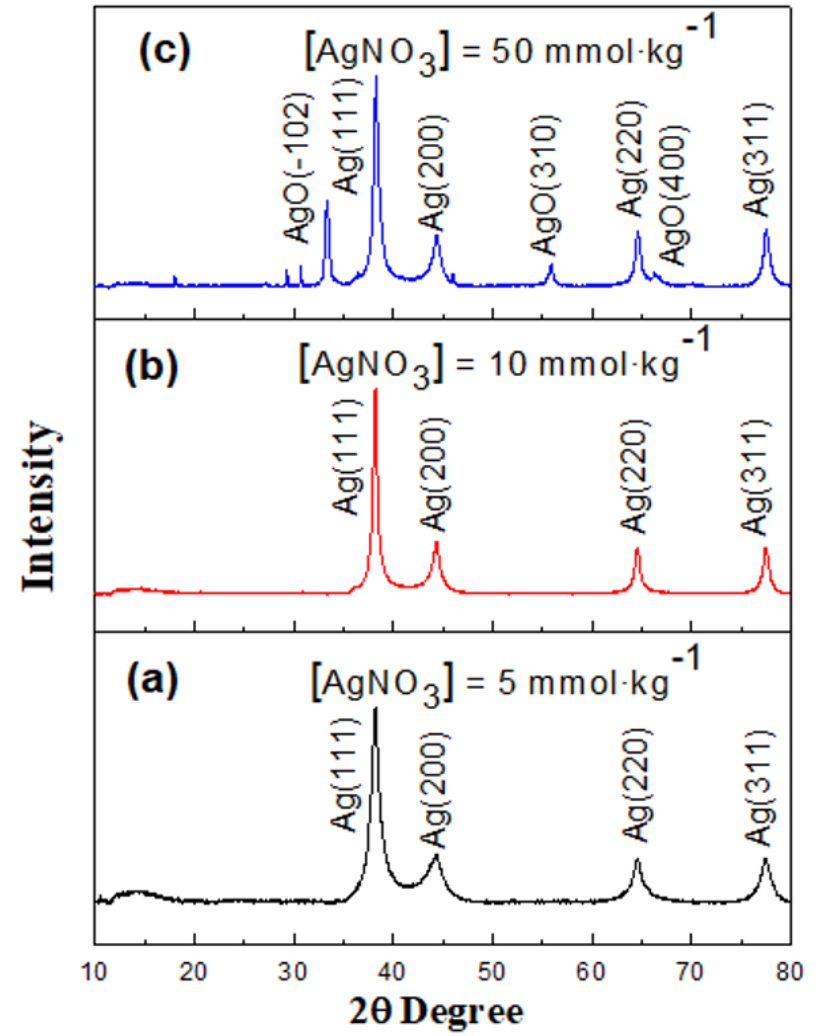

(B)

Figure 2: XRD spectra of Ag NPs synthesised by using (A) Aloe barbadensis miller and (B) Ocimum tenuiflorum leaf extracts at different concentrations of the precursor $\mathrm{AgNO}_{3}(\mathrm{a}-\mathrm{c})$

Table 2: The crystallite size (D), inter-planer spacing (d), lattice parameters (a, b, c), and volume (V) calculated for cubic crystal structure of Ag NPs synthesized at different concentrations of the precursor $\mathrm{AgNO}_{3}$ by using Aloe barbadensis miller and Ocimum tenuiflorum leaf extracts

\begin{tabular}{cccccc}
\hline Leaf Extract & {$\left[\mathrm{AgNO}_{3}\right]\left(\mathrm{mmol} \cdot \mathrm{kg}^{-1}\right)$} & $D(\mathrm{~nm})$ & $d(\mathrm{~nm})$ & $a=b=c(\mathrm{~nm})$ & $\left.V(\mathrm{~nm})^{3}\right)$ \\
\hline \multirow{3}{*}{ Aloe barbadensis miller } & 5 & 14.319 & 0.244 & 0.406 & 6.688 \\
& 10 & 16.647 & 0.235 & 0.407 & 6.758 \\
\hline \multirow{3}{*}{ Ocimum tenuiflorum } & 50 & 10.689 & 0.234 & 0.406 & 6.669 \\
& 5 & 8.113 & 0.235 & 0.407 & 6.764 \\
& 10 & 13.427 & 0.235 & 0.407 & 6.772 \\
\hline
\end{tabular}

tion of monoclinic unit cell volume and lattice parameters, respectively. The calculated values are tabulated in Table 2 .

$$
\begin{gathered}
D=\frac{0.94 \lambda}{\beta \cos \theta} \\
n \lambda=2 d \sin \theta \\
V=a^{3} \\
\frac{1}{d_{h k l}^{2}}=\frac{h^{2}+k^{2}+l^{2}}{a^{2}}
\end{gathered}
$$

Here, $\lambda=1.5406 \AA$ is the wavelength used during XRD analysis, $\beta$ is full width at half maximum (FWHM) for the most intense peak, $\theta$ is Bragg's angle, $(h, k, l)$ are Miller indices, $d_{h k l}$ is inter-planar spacing, $(a=b=c)$ are unit cell lattice parameters, and $V$ is the unit cell volume of the fcc crystal system of Ag NPs. 


\subsection{SEM/EDS Analysis}

The surface morphology and topography of synthesised Ag NPs was determined by employing the SEM technique. From SEM images displayed in Figure 3A-3C, it is clear that Ag NPs are showing the fluffy arrangement of small spheres, when synthesised at 5,10 , and $50 \mathrm{mmol} \cdot \mathrm{kg}^{-1}$ of the precursor $\mathrm{AgNO}_{3}$ by using the Aloe barbadensis miller leaf extract. In addition, the SEM images of Ag NPs synthesised by using the Ocimum tenuiflorum leaf extract are representing the formation of NPs with spherical/spheroidal shape (Figure 3D-3F)

The representative EDS spectra (Figure 4) enumerate the elemental analysis of the Ag NPs synthesised by using Aloe barbadensis miller leaf extract. All such spectra show the presence of both silver and oxygen elements in the

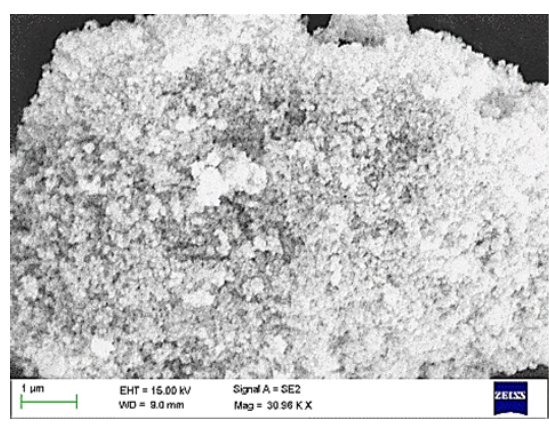

(A) $\left[\mathrm{AgNO}_{3}\right]=5 \mathrm{mmol} \cdot \mathrm{kg}^{-1}$

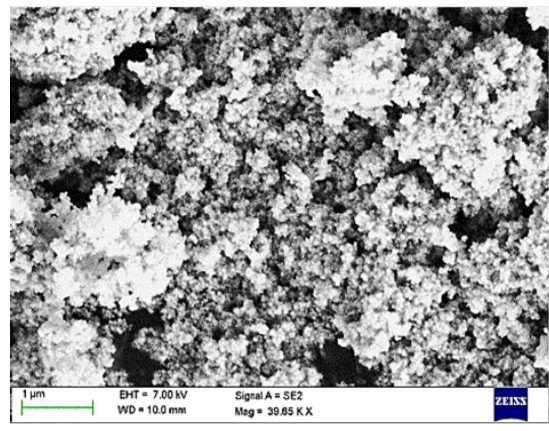

(D) $\left[\mathrm{AgNO}_{3}\right]=5 \mathrm{mmol} \cdot \mathrm{kg}^{-1}$

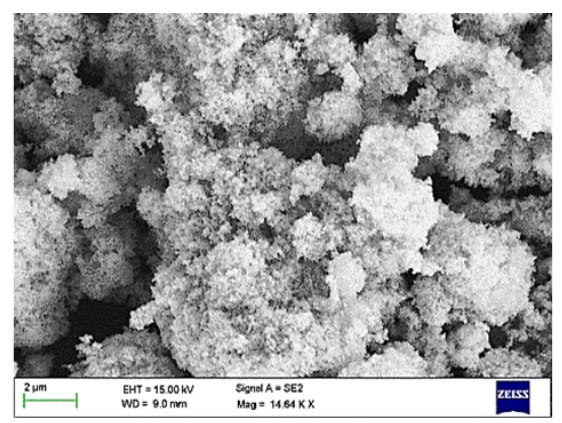

(B) $\left[\mathrm{AgNO}_{3}\right]=10 \mathrm{mmol} \cdot \mathrm{kg}^{-1}$

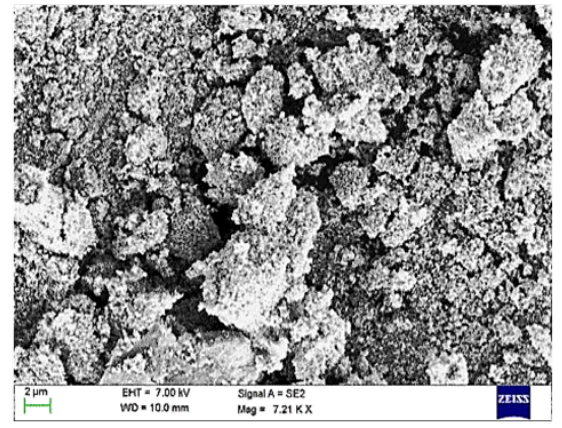

(E) $\left[\mathrm{AgNO}_{3}\right]=10 \mathrm{mmol} \cdot \mathrm{kg}^{-1}$

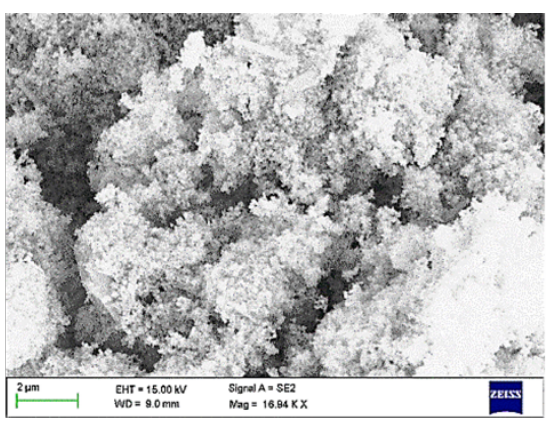

(C) $\left[\mathrm{AgNO}_{3}\right]=50 \mathrm{mmol} \cdot \mathrm{kg}^{-1}$

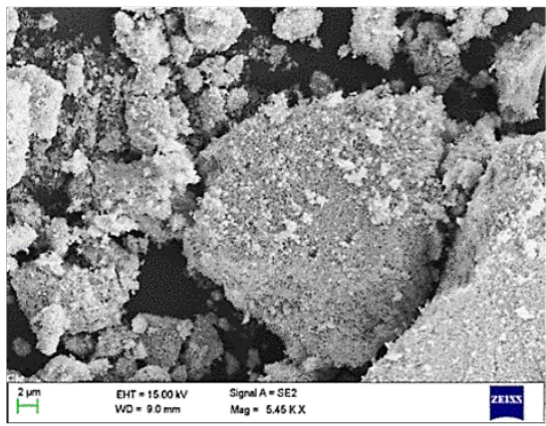

(F) $\left[\mathrm{AgNO}_{3}\right]=50 \mathrm{mmol} \cdot \mathrm{kg}^{-1}$

Figure 3: SEM images of Ag NPs synthesised by using Aloe barbadensis miller (A-C) and Ocimum tenuiflorum (D-F) leaf extracts at different concentrations of $\mathrm{AgNO}_{3}$

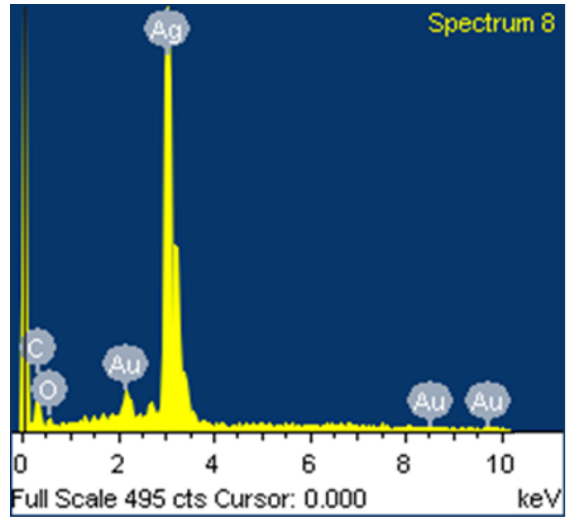

(A) $\left[\mathrm{AgNO}_{3}\right]=5 \mathrm{mmol} \cdot \mathrm{kg}^{-1}$

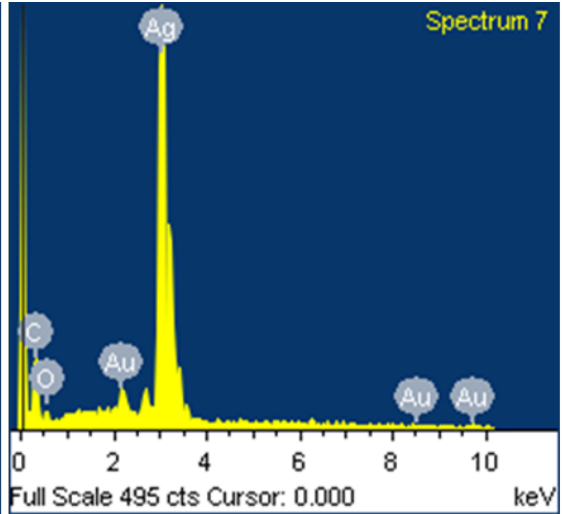

(B) $\left[\mathrm{AgNO}_{3}\right]=10 \mathrm{mmol} \cdot \mathrm{kg}^{-1}$

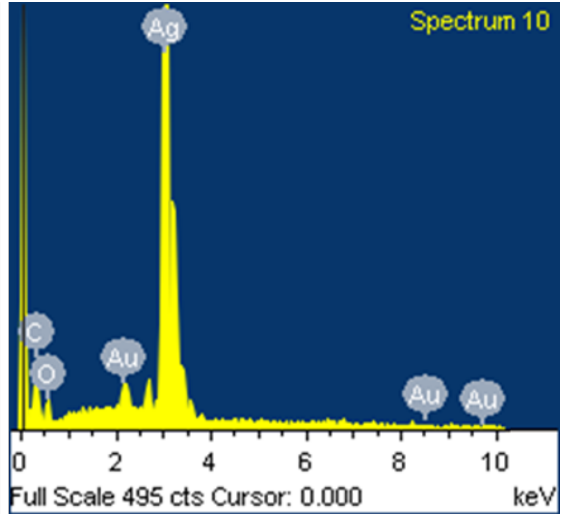

(c) $\left[\mathrm{AgNO}_{3}\right]=50 \mathrm{mmol} \cdot \mathrm{kg}^{-1}$

Figure 4: Representative EDS spectra of Ag NPs synthesised by using Aloe barbadensis miller leaf extract at different concentrations of $\mathrm{AgNO}_{3}(\mathrm{~A}-\mathrm{C})$ 
synthesised nano-material. The low-intensity peaks can be attributed to the occurrence of Au in coating the material used for EDS analysis experiments. However, the existence of elemental carbon peak may be due to the phytochemicals involved in the stabilisation of Ag NPs synthesised from the leaf extract. Similar spectra were obtained for the Ag NPs synthesised by sing Ocimum tenuiflorum leaf extract.

\subsection{TEM Analysis}

Both the size and shape of the biosynthesised Ag NPs were further characterised by transmission electron microscopy (TEM) analysis. From the analysis of the TEM micrograph images (Figure 5), it is found that the all samples of NPs synthesised at 5,10 , and $50 \mathrm{mmol} \cdot \mathrm{kg}^{-1}$ of $\mathrm{AgNO}_{3}$ were obviously exhibiting nearly similar spherical and spheroidal shapes for both the investigated plants. In contrast, the size of NPs is reflecting the effect of the type of leaf extract used and the precursors' concentration as well. At $5 \mathrm{mmol} \cdot \mathrm{kg}^{-1}$

of $\mathrm{AgNO}_{3}$, the Aloe barbadensis miller and Ocimum tenuiflorum synthesised Ag NPs show average size around 31.9 and $13.5 \mathrm{~nm}$, respectively. Further, the particle size generally increases with an increase in the concentration of $\mathrm{AgNO}_{3}$, as reported in Table 3. The obtained results are found in good

Table 3: Size range and average size of Ag NPs synthesised by using Aloe barbadensis miller and Ocimum tenuiflorum leaf extracts at different concentrations of $\mathrm{AgNO}_{3}$

\begin{tabular}{cccc}
\hline Leaf Extract & $\begin{array}{c}{\left[\mathrm{AgNO}_{3}\right]} \\
\left(\mathrm{mmol} \mathrm{kg}^{-1}\right)\end{array}$ & $\begin{array}{c}\text { Size } \\
\text { range }\end{array}$ & $\begin{array}{c}\text { Average } \\
\text { particle } \\
\text { size }\end{array}$ \\
\hline Aloe barbadensis & 5 & $20-66$ & 31.9 \\
miller & 10 & $27-70$ & 45.8 \\
& 50 & $7-65$ & 28.2 \\
\hline Ocimum & 5 & $9-25$ & 13.5 \\
tenuiflorum & 10 & $17-35$ & 24.5 \\
& 50 & $20-48$ & 32.5 \\
\hline
\end{tabular}

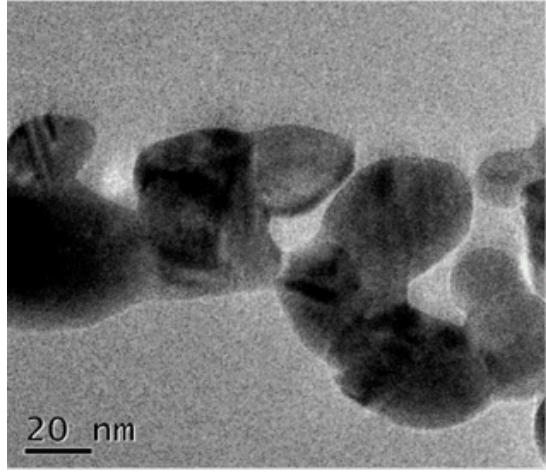

(A) $\left[\mathrm{AgNO}_{3}\right]=5 \mathrm{mmol} \cdot \mathrm{kg}^{-1}$

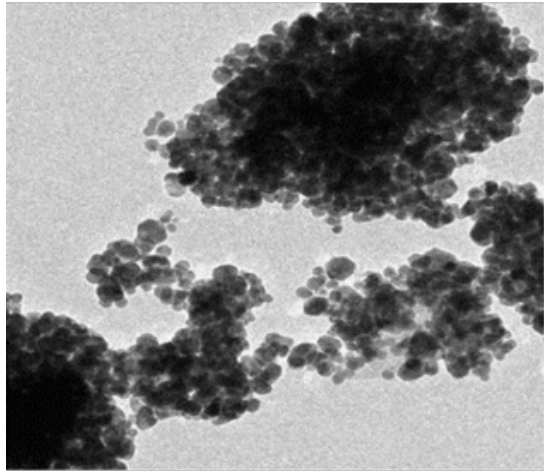

(D) $\left[\mathrm{AgNO}_{3}\right]=5 \mathrm{mmol} \cdot \mathrm{kg}^{-1}$

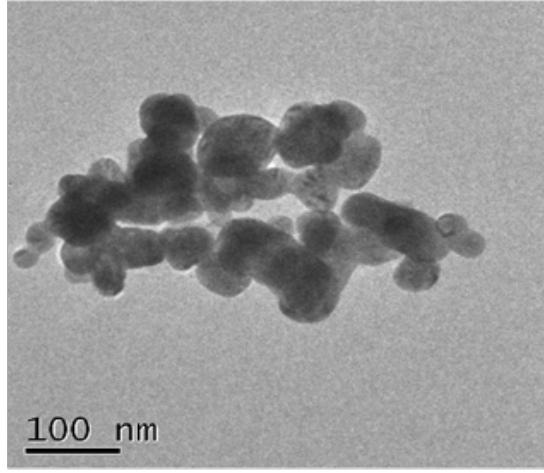

(B) $\left[\mathrm{AgNO}_{3}\right]=10 \mathrm{mmol} \cdot \mathrm{kg}^{-1}$

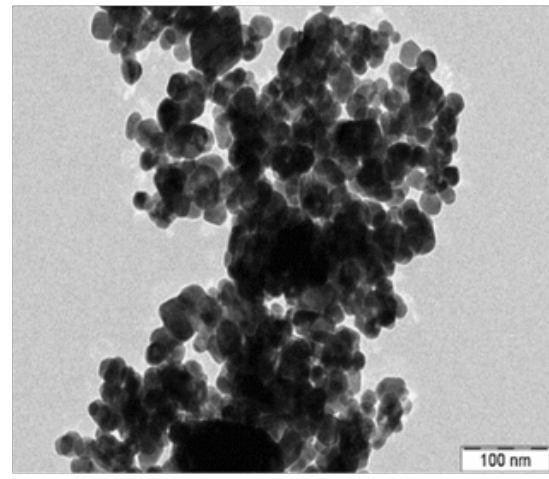

(E) $\left[\mathrm{AgNO}_{3}\right]=10 \mathrm{mmol} \cdot \mathrm{kg}^{-1}$

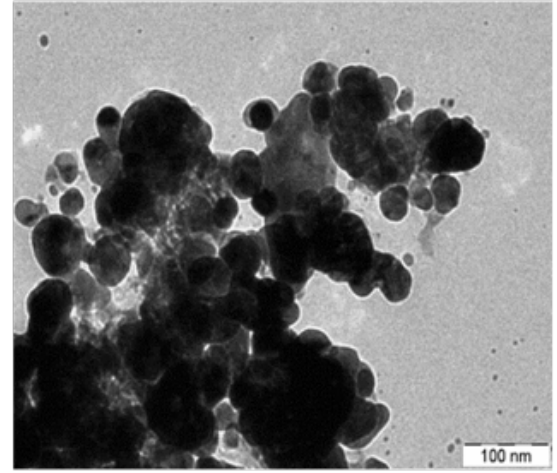

(C) $\left[\mathrm{AgNO}_{3}\right]=50 \mathrm{mmol} \cdot \mathrm{kg}^{-1}$

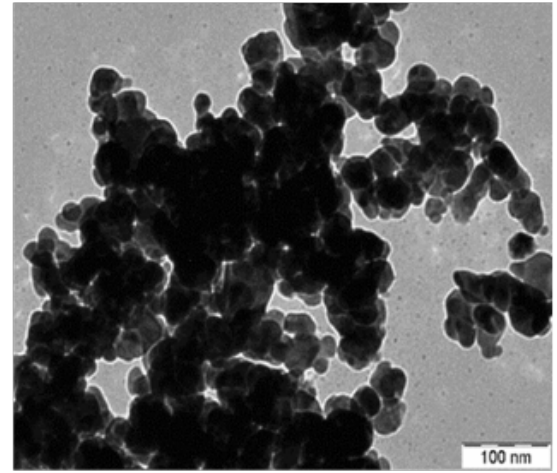

(F) $\left[\mathrm{AgNO}_{3}\right]=50 \mathrm{mmol} \cdot \mathrm{kg}^{-1}$

Figure 5: TEM images of silver NPs synthesised by using Aloe barbadensis miller (A-C) and Ocimum tenuiflorum (D-F) leaf extracts at different concentrations of $\mathrm{AgNO}_{3}$ 


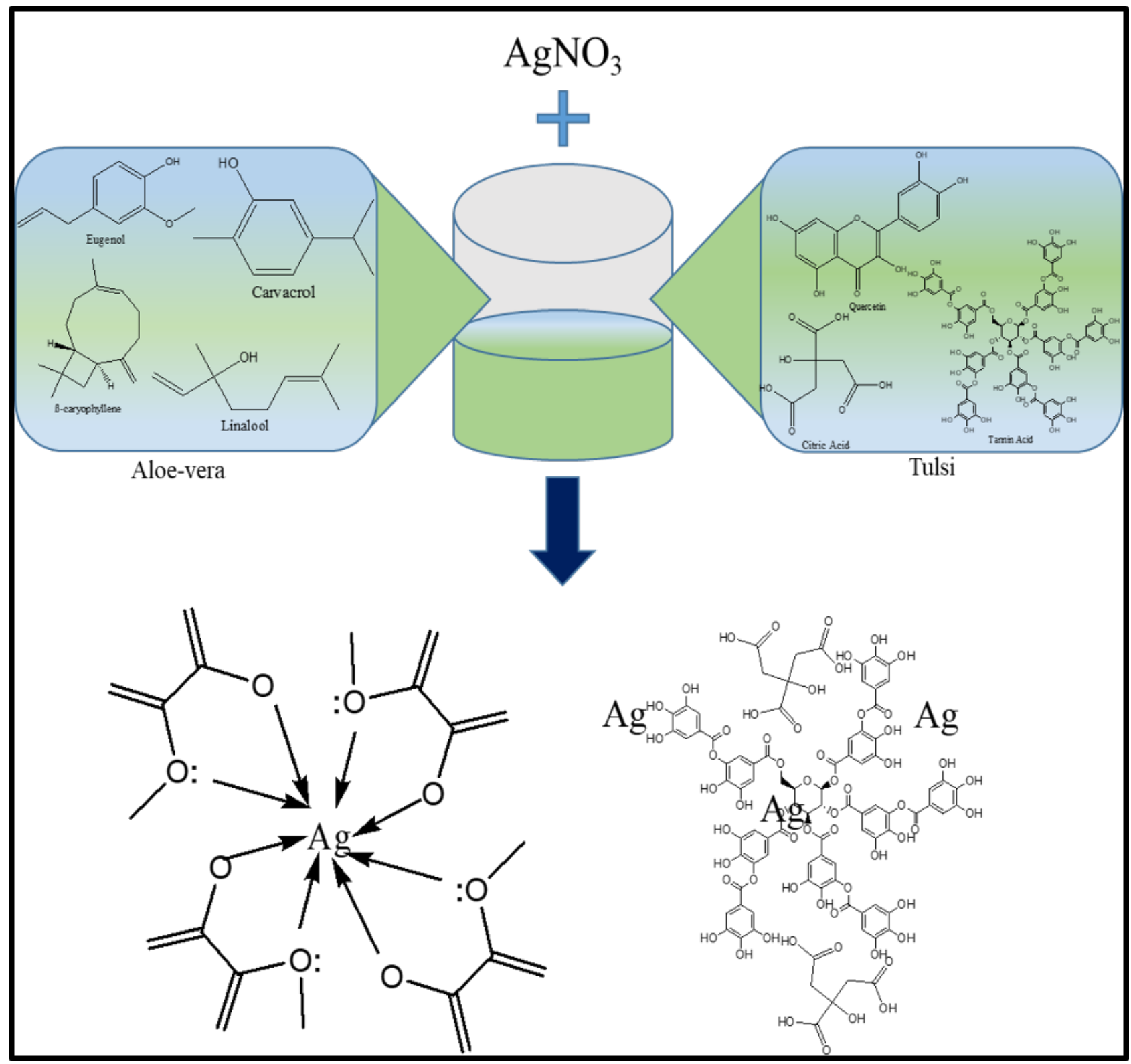

Figure 6: Chemistry or role of the phytochemicals in the synthesis of Ag NPs by using Aloe barbadensis miller or Ocimum tenuiflorum leaf extracts

agreement with the results reported by Ghozali et al., where NPs are synthesised by using the $\mathrm{AgNO}_{3}$ and C. roseus aqueous extract [80]. On the other hand, Logaranjan et al. have reported the Aloe barbadensis miller synthesised Ag NPs, which were mostly spherical in shape with an average size of 5-50 nm [81].

From Table 3, it is interesting to note that the particles synthesized by using the Ocimum tenuiflorum leaf extract are comparatively smaller in size as compare to those synthesised by using Aloe barbadensis miller leaf extract. However, at $50 \mathrm{mmol} \cdot \mathrm{kg}^{-1}$ of $\mathrm{AgNO}_{3}$ a remarkable wide range smaller size $(7-65 \mathrm{~nm}) \mathrm{Ag}$ NPs were formed when syn- thesised by using the Aloe barbadensis miller leaf extract (Figure 5 and Table 3). Such type of large range in size can be attributed to the formation of mixed silver and silver oxide NPs, as also indicated in XRD patterns. Moreover, the exceptional results of Aloe barbadensis miller at $50 \mathrm{mmol} \cdot \mathrm{kg}^{-1}$ of $\mathrm{AgNO}_{3}$ may be due to active stabilisation or capping of the synthesised nano-crystals by aloin or other phytochemicals present in the leaf extract.

In the light of the above discussion, the mechanism of bio-synthesis of Ag NPs can be demonstrated as shown in Figure 6. Both, the Aloe barbadensis miller and Ocimum tenuiflorum leaf extracts are the rich source of various phyto- 
chemicals. Jain and Mehata [57], Logaranjan et al. [81], and Brahmachari et al. [82] have reported the role of Quercetin (present in Ocimum tenuiflorum), Aloin (found in Aloe barbadensis miller), and the Eugenol phytochemicals, respectively, in the mechanism of the bio-synthesis of Ag NPs. The presence of metabolites like anthraquinones, polyphenols, polysaccharides, lignins, saponins, alcohols, amino acids, fatty acids, sterols, etc. [83, 84] in Aloe barbadensis miller and biologically active compounds like eugenol, urosolic acid, linalool, carvacrol, limatrol, luteolin, vitexin, orientin, chlorogenic acid, caffeic acid, rosmarinic acid, ascorbic acid, etc. in Ocimum tenuiflorum are the phytochemicals which are held responsible for their involvement in the synthesis of NPs [85].

\subsection{Anti-bacterial Activity}

Figure 7 illustrates the anti-bacterial activity of biosynthesised Ag NPs in terms of zones of inhibition, as investigated under the Agar well diffusion method against pathogens, Bacillus subtilis, Staphylococcus aureus, and Escherichia coli. The so-calculated values of zones of inhibition (Figure 7) are summarised in Table 4 for both Aloe barbadensis miller and Ocimum tenuiflorum mediated nanosamples. The maximum zones of inhibition for the Aloe barbadensis miller $(15.67 \pm 1.28 \mathrm{~mm})$ and Ocimum tenuiflorum $(12.45 \pm 1.18 \mathrm{~mm})$ synthesised Ag NPs have been observed against Escherichia coli, whereas against Bacillus subtilis, almost all the synthesised samples show minimum zone of inhibition. Further, all the synthesised samples, except few, found to be inactive against Staphylococcus aureus (Ta-

Table 4: Zones of inhibition of Ag NPs synthesised by using Aloe barbadensis miller and Ocimum tenuiflorum leaf extracts at different concentrations of $\mathrm{AgNO}_{3}$ against different bacteria

\begin{tabular}{|c|c|c|c|c|}
\hline \multirow{2}{*}{ Bacteria } & \multirow{2}{*}{$\begin{array}{c}{\left[\mathrm{AgNO}_{3}\right]} \\
\left(\mathrm{mmol} \cdot \mathrm{kg}^{-1}\right)\end{array}$} & \multirow{2}{*}{$\begin{array}{c}\text { NPs } \\
\text { dosage } \\
(\mu \mathrm{g} / \mathrm{ml})\end{array}$} & \multicolumn{2}{|c|}{ Zone of inhibition $(\mathrm{mm})$} \\
\hline & & & $\begin{array}{l}\text { NPs synthesised using Aloe } \\
\text { barbadensis miller }\end{array}$ & $\begin{array}{c}\text { NPs synthesised using Ocimum } \\
\text { tenuiflorum }\end{array}$ \\
\hline \multirow{9}{*}{ Bacillus subtilis } & \multirow{3}{*}{5} & 100 & NA & NA \\
\hline & & 500 & NA & $6.5 \pm 0.7^{a}$ \\
\hline & & 1000 & $6.7 \pm 0.87^{a}$ & $7.65 \pm 1.27$ \\
\hline & \multirow{3}{*}{10} & 100 & $6.5 \pm 0.5$ & N.A. \\
\hline & & 500 & $6.9 \pm 1.33$ & $6.2 \pm 0.33$ \\
\hline & & 1000 & $7.2 \pm 0.75$ & $7.2 \pm 0.55$ \\
\hline & \multirow{3}{*}{50} & 100 & $9.7 \pm 1.11$ & $8.5 \pm 0.25$ \\
\hline & & 500 & $11.33 \pm 0.71$ & $11.40 \pm 0.62$ \\
\hline & & 1000 & $12.11 \pm 1.26$ & $11.51 \pm 1.36$ \\
\hline \multirow{9}{*}{$\begin{array}{c}\text { Staphylococcus } \\
\text { aureus }\end{array}$} & \multirow{3}{*}{5} & 100 & NA & NA \\
\hline & & 500 & NA & NA \\
\hline & & 1000 & NA & NA \\
\hline & \multirow{3}{*}{10} & 100 & NA & NA \\
\hline & & 500 & NA & NA \\
\hline & & 1000 & NA & NA \\
\hline & \multirow{3}{*}{50} & 100 & NA. & NA \\
\hline & & 500 & $7.5 \pm 1.13$ & NA \\
\hline & & 1000 & $8.8 \pm 1.07$ & $6.8 \pm 0.33$ \\
\hline \multirow{9}{*}{ Escherichia coli } & \multirow{3}{*}{5} & 100 & NA & NA \\
\hline & & 500 & $6.5 \pm 0.72$ & $7.9 \pm 0.92$ \\
\hline & & 1000 & $6.5 \pm 1.12$ & $8.5 \pm 0.41$ \\
\hline & \multirow{3}{*}{10} & 100 & NA & NA \\
\hline & & 500 & NA & NA \\
\hline & & 1000 & NA & $6.75 \pm 0.25$ \\
\hline & \multirow{3}{*}{50} & 100 & $12.626 \pm 1.82$ & $7.26 \pm 0.60$ \\
\hline & & 500 & $13.8 \pm 0.38$ & $12.40 \pm 0.38$ \\
\hline & & 1000 & $15.67 \pm 1.28$ & $12.45 \pm 1.18$ \\
\hline
\end{tabular}

\footnotetext{
${ }^{a}$ Standard error in measurement of zone of inhibition.
} 


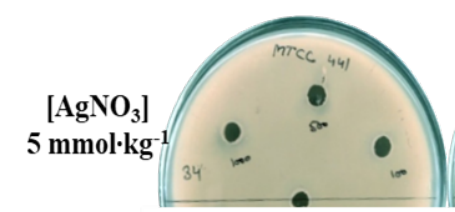

(a)

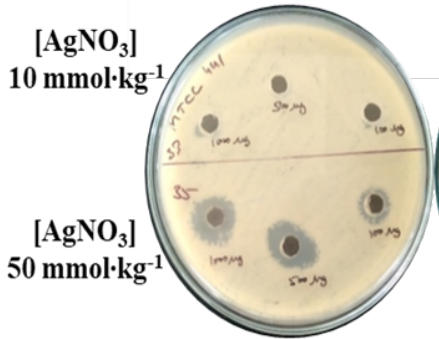

(d)

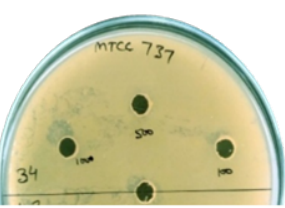

(b)

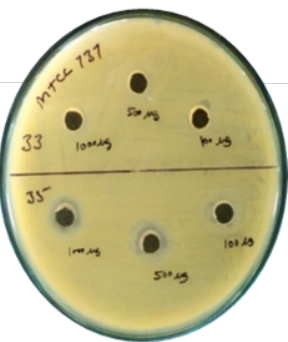

(e)

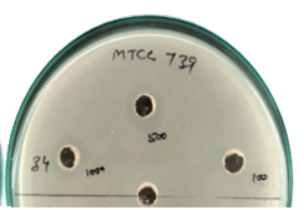

(c)

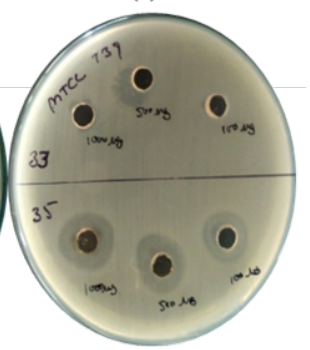

(f)

(A)

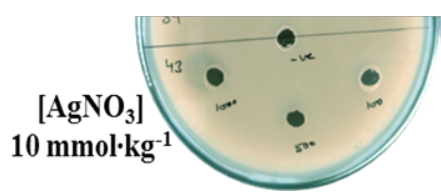

(a)

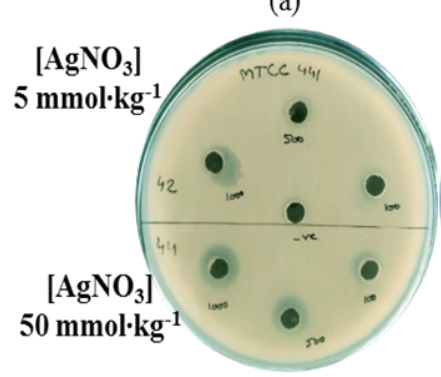

(d)

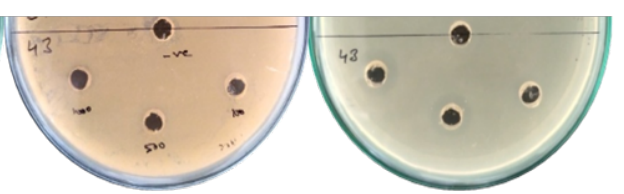

(b)

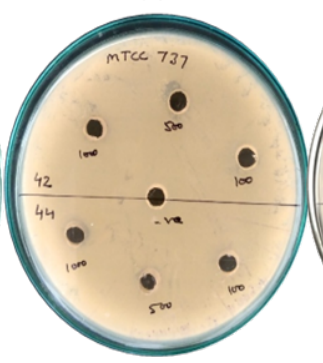

(e) (c)

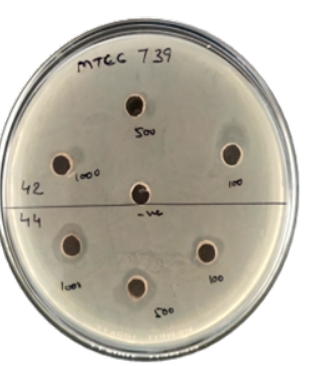

(f)

(B)

Figure 7: Zones of inhibition of Ag NPs synthesised by using (A) Aloe barbadensis miller and (B) Ocimum tenuiflorum leaf extracts at different concentrations of $\mathrm{AgNO}_{3}$ against (a, d) Bacillus subtilis, (b, e)Staphylococcus aureus, and (c, f) Escherichia coli

ble 4). The so-obtained results can be compared with 10.5 to $7.5 \mathrm{~mm}$ values as reported by Anandalakshmi et al. [86]. Similar results have been demonstrated by Chauhan et al. [87] for the anti-bacterial activity of Ag NPs synthesised by using pathogen Pichia fermentans JA2.

Exceptionally, the samples obtained at $50 \mathrm{mmol} \cdot \mathrm{kg}^{-1}$ of $\mathrm{AgNO}_{3}$ in the presence of both Aloe barbadensis miller and Ocimum tenuiflorum plant extracts, are very effective to inhibit the growth of all the studied human pathogens (Figure 7 and Table 4). This exceptional behaviour may be attributed to the presence of AgO nano-structure in addition to $\mathrm{Ag}$ in the samples synthesised at the $50 \mathrm{mmol} \cdot \mathrm{kg}^{-1}$ of $\mathrm{AgNO}_{3}$, as already concluded from the XRD studies. A very small information has been found in the literature on the anti-bacterial activity of the AgO NPs. Vithiya et al. [88] have carried out the anti-bacterial activity study of $\mathrm{Ag}_{2} \mathrm{O}$

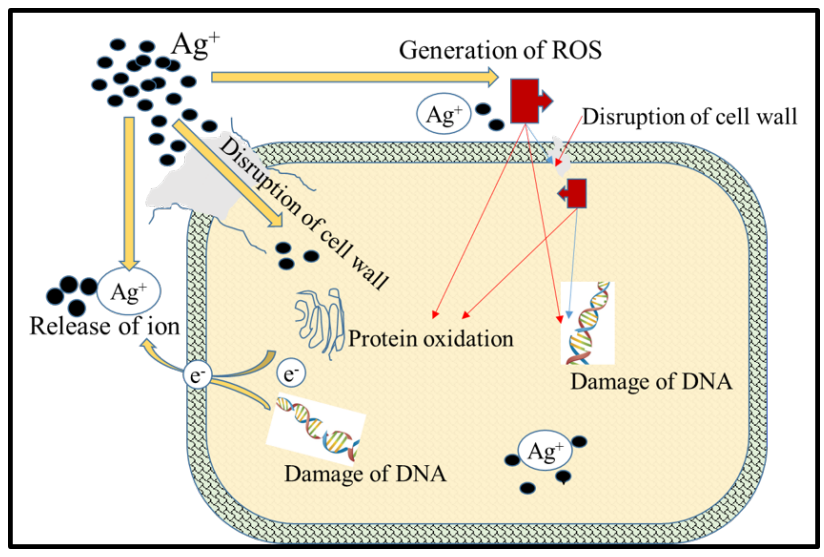

Figure 8: Mechanism for the anti-bacterial action of Ag NPs 
NPs at $1.69 \mathrm{mg} / \mathrm{ml}$ and Dharmaraj et al. [89] have examined the antibiofilm activity and cytotoxic potentiality of $\mathrm{Ag}_{2} \mathrm{O}$ at a very low amount. Moreover, the high activity of the AgO NPs as compared to the Ag NPs may be correlated with the ease of the generation of the active $\mathrm{Ag}$ ion during the anti-bacterial action. The Ag ions are stronger anti-bacterial agents than the Ag metal [90]. In the possible mechanism for the anti-bacterial action (Figure 8), the Ag ions penetrate the cell wall and disrupt the cellular function by interacting with the sulphur component present in the plasma membrane. The Van der Walls forces, electrostatics attractions, hydrophobic interactions, etc. change the metabolic action and NPs can easily penetrate the bacterial membrane. NPs' interactions with the bacterial components like DNA, ribo-

Table 5: MIC and MBC values of Ag NPs synthesised by using Aloe barbadensis miller and Ocimum tenuiflorum leaf extracts at different concentrations of $\mathrm{AgNO}_{3}$

\begin{tabular}{cccccc}
\hline \multirow{2}{*}{ Bacteria } & $\begin{array}{c}{\left[\mathrm{AgNO}_{3}\right]} \\
\left(\mathrm{mmol}^{-} \cdot \mathrm{kg}^{-1}\right)\end{array}$ & $\begin{array}{c}\text { Aloe } \\
\text { barbadensis } \\
\text { miller }\end{array}$ & $\begin{array}{c}\text { Ocimum } \\
\text { tenuiflorum }\end{array}$ & $\begin{array}{c}\text { Aloe } \\
\text { barbadensis } \\
\text { miller }\end{array}$ & $\begin{array}{c}\text { Ocimum } \\
\text { tenuiflorum }\end{array}$ \\
\cline { 3 - 6 } Bacillus subtilis & 5 & 125 & 62.5 & 2000 & 1000 \\
& 10 & 250 & 250 & 2000 & 1000 \\
& 50 & 62.5 & 62.5 & 1000 & 500 \\
\hline Staphylococcus & 5 & 125 & 125 & 500 & 1000 \\
aureus & 10 & 250 & 250 & 500 & 1000 \\
& 50 & 125 & 125 & 500 & 500 \\
\hline \multirow{2}{*}{ Escherichia coli } & 5 & 125 & 125 & 500 & 500 \\
& 10 & 250 & 250 & 1000 & 500 \\
& 50 & 125 & 125 & 500 & 500 \\
\hline
\end{tabular}

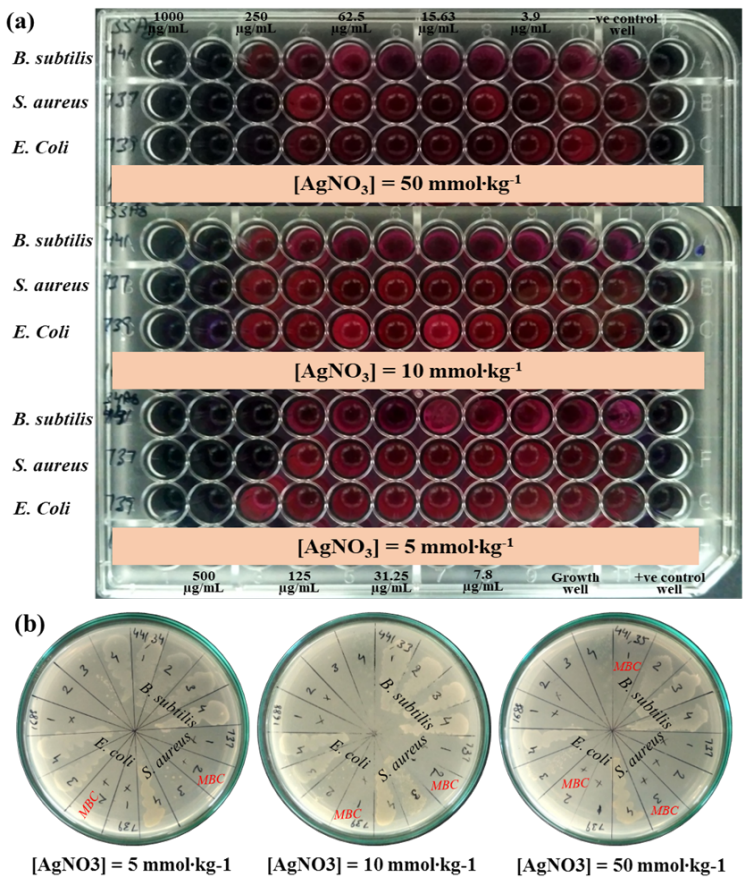

(A)

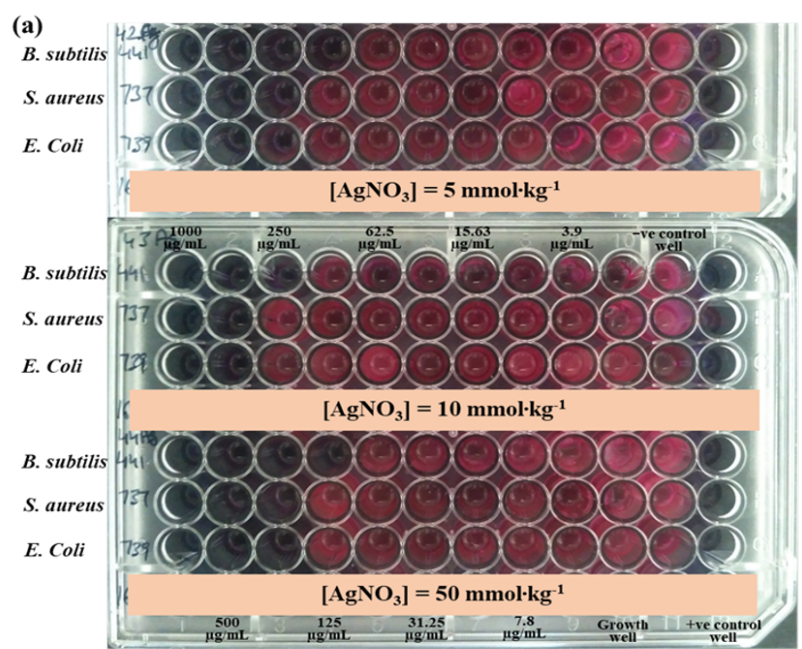

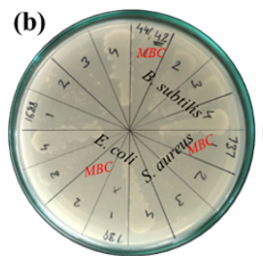

$\left[\mathrm{AgNO}_{3}\right]=5 \mathrm{mmol} \cdot \mathrm{kg}^{-1}$

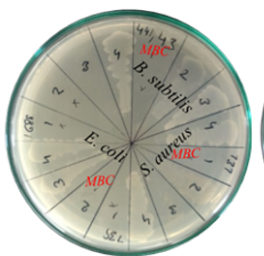

$\left[\mathrm{AgNO}_{3}\right]=10 \mathrm{mmol} \cdot \mathrm{kg}^{-1}$

(B)

Figure 9: The (a) MIC and (b) MBC values of Ag NPs synthesised by using (A) Aloe barbadensis miller and (B) Ocimum tenuiflorum leaf extracts at different concentrations of $\mathrm{AgNO}_{3}$ 
somes, enzymes etc. lead to the oxidative stress, electrolyte unbalancing, enzyme and protein disruption, etc., and ultimately cause the bacterial death [91]. In addition, the generation of reactive oxygen species (ROS), and other types of interactions of the Ag ions with the membrane (Figure 8) are also the possible reasons for the high anti-bacterial action of the AgO NPs [92]. The high activity against the gram-negative Escherichia coli than gram-positive Bacillus subtilis and Staphylococcus aureus is due to the thin cell wall of the Escherichia coli [93]. It has also been observed that a large amount of ROS generated in case of the gramnegative Escherichia coli, which produces the high activity oxidative stress over Escherichia coli [94, 95]. In addition, the NPs prevent the production of bio-film by the microbes to resist the drug action and hence, better results are obtained in case of NPs [96]. In the light of above discussion, the mechanism of antibacterial action can be divided into three parts, namely, penetration of the cell wall, generation of ROS, and release of the metal ions. Along with the antibacterial action, the cytotoxic studies and NPs intracellular interactions with ROS are the important aspects that can be correlated to cell growth and a probable mechanism for antibacterial action of the AgO NPs on the different bacterial pathogens.

Figure 9 picturised the MIC and MBC results, which are tabulated in Table 5. In case of all studied bacteria, the MIC and MBC values are lowest for the Ag NPs synthesised at $50 \mathrm{mmol} \cdot \mathrm{kg}^{-1} \mathrm{AgNO}_{3}$. The MIC and MBC values are varying between 62.5 to 250 and 500 to $2000 \mu \mathrm{g} / \mathrm{mL}$, respectively. Rout et al. [97] reported more than $11 \mathrm{mg} / \mathrm{ml}$ MIC for biosynthesised Ag NPs against different bacteria. Wypij et al. [98] show 64 and $256 \mu \mathrm{g} / \mathrm{ml}$ MIC against the Bacillus subtilis/Escherichia coli and Staphylococcus aureus, respectively, for Ag NPs synthesised from Streptomyces xinghaiensis OF1 strain. Moreover, Yadav et al. [99] reported the MIC values in a range of 195 to $780 \mu \mathrm{g} / \mathrm{ml}$ for Ag NPs prepared by using Aloe barbadensis miller against different bacterial strains.

\section{Conclusions}

Ag NPs with tuneable characteristics for customised applications were synthesised using Aloe barbadensis miller and Ocimum tenuiflorum leaf extracts in the present work. The effect of precursor, $\mathrm{AgNO}_{3}$ concentration on the chemical and biophysical properties of the nanostructures was also investigated. The XRD spectral studies confirm the formation of mixed $\mathrm{Ag}+\mathrm{AgO}$ crystal phase at $50 \mathrm{mmol} \cdot \mathrm{kg}^{-1}$ of $\mathrm{AgNO}_{3}$. The TEM analysis illustrated that the particles are mostly spherical and possess an average size in the range of 7-70 and 9-48 $\mathrm{nm}$ when synthesised from the Aloe barbadensis miller and Ocimum tenuiflorum leaf extracts, respectively. The nano-samples synthesised at 50 $\mathrm{mmol} \cdot \mathrm{kg}^{-1}$ of $\mathrm{AgNO}_{3}$ have shown very high anti-bacterial inhibition property due to the presence of $\mathrm{AgO}$ in addition to Ag nano-structures. Further, the largest zone of inhibition was found in the Escherichia coli for all the prepared nano-samples. Thus, study revealed that the precursor concentration and leaf extract compositions play a key role in describing the features of the Ag NPs and their application as potent anti-bacterial agents. It can also be concluded that a very less research has been reported on AgO nanostructures, hence this field need to be explored particularly in terms of biomedical applications. This work creates an opportunity to a facile and low-cost bio-synthesis approach to synthesise highly bio-active Ag NPs. However, the supplementary studies are required to profoundly examine the cytotoxic effects of the prepared NPs. Moreover, the ability of the bio-synthesized NPs to alter the intracellular ROS levels will also be a new area to be assessed in future.

Acknowledgement: The authors are grateful to the Department of Chemistry and Centre for Nano-Science and Technology, Career Point University Hamirpur (HP), India for providing the all required facilities to carry out the work.

Funding information: This research received no specific grant from any funding agencies, all funds are settled by authors.

Authors' contribution: The manuscript writing, conceptualization, and methodology contributed by Saurabh Sharma, under the supervision and project administration of Kuldeep Kumar and Naveen Thakur. The validation, visualization, review and editing executed by Kuldeep Kumar.

Conflicts of interests: The authors declare no competing financial interest.

Ethical approval: The conducted research is not related to either human or animal use.

Data availability: All data generated or analysed during this study are included in this published article. 


\section{References}

[1] Rana AK, Frollini E, Thakur VK. Cellulose nanocrystals: Pretreatments, preparation strategies, and surface functionalization. Int J Biol Macromol. 2021 Jul;182:1554-81.

[2] Rana AK, Potluri P, Thakur VK. Cellulosic Grewia optiva fibres: towards chemistry, surface engineering and sustainable materials. J Environ Chem Eng. 2021;9(5):106059.

[3] Wei S, Wang Y, Tang Z, Hu J, Su R, Lin J, et al. A Size controlled green synthesis of silver nanoparticles by using the berry extract of sea Buckthorn and their biological activities. New J Chem. 2020;44(22):9304-12.

[4] Lagashetty A. Green synthesis and characterisation of silver nanoparticles using Piper betle leaf extract. Bull. Adv. Sci. Res. 2015;1:136-8.

[5] Amarendra DD. Biosynthesis of silver and gold nanoparticles using Chenopodium album leaf extracts. Colloids Surf A Physicochem Eng Asp. 2010;369(1-3):27-33.

[6] Anastas PT, Warner JC. Green chemistry: theory and practice. Oxford university press; 2000

[7] Kalaiarasi R, Jayallakshmi N, Venkatachalam P. Phytosynthesis of nanoparticles and its applications - a review. Plant Cell Biotechnol Mol Biol. 2010;11:1-16.

[8] Iravani S. Green synthesis of metal nanoparticles using plants. Green Chem. 2011;13(10):2638-50.

[9] Vaidyanathan R, Gopalram S, Kalishwaralal K, Deepak V, Pandian $S R$, Gurunathan S. Enhanced silver nanoparticle synthesis by optimization of nitrate reductase activity. Colloids Surf B Biointerfaces. 2010 Jan;75(1):335-41.

[10] Iravani S, Korbekandi H, Mirmohammadi SV, Mekanik H. Mechanism and applications of metal nanoparticles prepared by biomediated process. Rev. Adv. Sci. Eng. 2014;3:261-74.

[11] Korbekandi H, Iravani S, Abbasi S. Production of nanoparticles using organisms. Crit Rev Biotechnol. 2009;29(4):279-306.

[12] Emmanuel R, Palanisamy S, Chen SM, Chelladurai K, Padmavathy $S$, Saravanan M, et al. Antimicrobial efficacy of green synthesized drug blended silver nanoparticles against dental caries and periodontal disease causing microorganisms. Mater Sci Eng C. 2015 Nov;56:374-9.

[13] Prathna TC. MathewL,ChandrasekaranN, Raichur AM, MukherjeeA.Biomimetic Synthesis of Nanoparticles: Science, Technology \& Applicability.In BiomimeticsLearning from Nature, ed. A. Mukherjee, InTech, 2010.

[14] Arokiyaraj S, Kumar VD, Elakya V, Kamala T, Park SK, Ragam M, Saravanan M, Bououdina M, Arasu MV, Kovendan K, Vincent S.Biosynthesised silver nanoparticles using floral extract of Chrysanthemum indicum L.-potential for malaria vector control. Environ. Sci. Pollut. Res. 2015; 22:9759-9765.

[15] Prakash P, Gnanaprakasam P, Emmanuel R, Arokiyaraj S, Saravanan $M$. Green synthesis of silver nanoparticles from leaf extract of Mimusops elengi, Linn. for enhanced antibacterial activity against multi drug resistant clinical isolates. Colloids Surf B Biointerfaces. 2013 Aug;108:255-9.

[16] Machado S, Grosso JP, Nouws HP, Albergaria JT, Delerue-Matos C. Utilization of food industry wastes for the production of zerovalent iron nanoparticles. Sci Total Environ. 2014 Oct;496:23340.

[17] Lakshmipathy R, Palakshi-Reddy B, Sarada NC, Chidambaram $\mathrm{K}$, Pasha SK. Watermelon rind-mediated green synthesis of no- ble palladium nanoparticles: catalytic application. Appl Nanosci. 2015;5(2):223-8.

[18] Maity D, Pattanayak S, Mollick MM, Rana D, Mondal D, Bhowmick $B$, et al. Green one step morphosynthesis of silver nanoparticles and their anti-bacterial and anticancerous activities. New J Chem. 2016;40(3):2749-62.

[19] Patil MP, Palma J, Simeon NC, Jin X, Liu X, Ngabire D, et al. Sasa borealis leaf extract-mediated green synthesis of silver-silver chloride nanoparticles and their anti-bacterial and anticancer activities. New J Chem. 2017;41(3):1363-71.

[20] Xu L, Wang YY, Huang J, Chen CY, Wang ZX, Xie H. Silver nanoparticles: Synthesis, medical applications and biosafety. Theranostics. 2020 Jul;10(20):8996-9031.

[21] Burduşel AC, Gherasim 0, Grumezescu AM, Mogoantă L, Ficai A, Andronescu E. Biomedical applications of silver nanoparticles: an up-to-date overview. Nanomaterials (Basel). 2018 Aug;8(9):125.

[22] Barani M, Rahdar A, Sargazi S, Amiri MS, Sharma PK, Bhalla N. Nanotechnology for inflammatory bowel disease management: Detection, imaging and treatment. Sens. Bio-Sens. Sens Biosensing Res. 2021;32:100417.

[23] Colino Cl, Lanao JM, Gutierrez-Millan C. Recent advances in functionalized nanomaterials for the diagnosis and treatment of bacterial infections. Mater Sci Eng C. 2021 Feb;121:111843.

[24] Barani M, Mukhtar M, Rahdar A, Sargazi S, Pandey S, Kang M. Recent Advances in Nanotechnology-Based Diagnosis and Treatments of Human Osteosarcoma. Biosensors (Basel). 2021 Feb;11(2):55.

[25] Arshad R, Barani M, Rahdar A, Sargazi S, Cucchiarini M, Pandey S, et al. Multi-Functionalized Nanomaterials and Nanoparticles for Diagnosis and Treatment of Retinoblastoma. Biosensors (Basel). 2021 Mar;11(4):97.

[26] Saravani R, Sargazi S, Saravani R, Rabbani M, Rahdar A, Taboada $P$. Newly crocin-coated magnetite nanoparticles induce apoptosis and decrease VEGF expression in breast carcinoma cells. J Drug Deliv Sci Technol. 2020;101987:101987.

[27] Rahdar A, Hajinezhad MR, Sargazi S, Bilal M, Barani M, Karimi $P$, et al. Biochemical effects of deferasirox and deferasiroxloaded nanomicellesin iron-intoxicated rats. Life Sci. 2021 Apr;270:119146.

[28] Flores-Gonzalez M, Talavera-Rojas M, Soriano-Vargas E, Rodriguez-Gonzalez V. Practical mediated-assembly synthesis of silver nanowires using commercial: camellia sinensis extracts and their anti-bacterial properties. New J Chem. 2018;42(3):2133-9.

[29] Sulthana RN, Rajanikanth A. Green Synthesis of Silver Nanoparticles Using Seed Extract of Foeniculum vulgare and their Antibacterial Activity. Int J Curr Res Biosci Plant Biol. 2018;5(7):7783.

[30] Asghar MA, Zahir E, Shahid SM, Khan MN, Asghar MA, Iqbal J, et al. Iron, Copper and Silver nanoparticles: green synthesis using green and black tea leaves extracts and evaluation of anti-bacterial, antifungal and aflatoxin B1 adsorption activity. Lebensm Wiss Technol. 2018;90:98-107.

[31] Fairuzi AA, Bonnia NN, Akhir RM, Abrani MA, Akil HM. Degradation of methylene blue using silver nanoparticles synthesised from imperata cylindrica aqueous extract. IOP Conf Ser Earth Environ Sci. 2018;105:1-6.

[32] Sorbiun M, Mehr SE, Ramazani A, Fardood S. Biosynthesis of $\mathrm{Ag}, \mathrm{ZnO}$ and bimetallic $\mathrm{Ag} / \mathrm{ZnO}$ alloy nanoparticles by aqueous 
extract of oak fruit hull (Jaft) and investigation of photocatalytic activity of $\mathrm{ZnO}$ and bimetallic $\mathrm{Ag} / \mathrm{ZnO}$ for degradation of basic violet 3 dye. J Mater Sci Mater Electron. 2018;29(4):2806-14.

[33] Shaik MR, Khan M, Kuniyil M, Al-Warthan A, Alkhathlan HZ, Siddiqui MR, et al. Plant-Extract-Assisted green synthesis of silver nanoparticles using Origanum vulgare L. Extract and their microbicidal activities. Sustainability (Basel). 2018;10(4):1-14.

[34] Oves M, Aslam M, Rauf MA, Qayyum S, Qari HA, Khan MS, et al. Antimicrobial and anticancer activities of silver nanoparticles synthesized from the root hair extract of Phoenix dactylifera. Mater Sci Eng C. 2018 Aug;89:429-43.

[35] Palanisamy K, Kalaiselvi PA, Gabriel M, Thangavel J, Sundaram L. Synthesis of anti-bacterial silver nanoparticles against human pathogens. World J Pharm Pharm Sci. 2019;3:2019-32.

[36] Du J, Hu Z, Yu Z, Li H, Pan J, Zhao D, et al. Antibacterial activity of a novel Forsythia suspensa fruit mediated green silver nanoparticles against food-borne pathogens and mechanisms investigation. Mater Sci Eng C. 2019 Sep;102:247-53.

[37] Aritonang HF, Koleangan H, Wuntu AD. Synthesis of silver nanoparticles using aqueous extract of medicinal plants' (Impatiens balsamina and Lantana camara) fresh leaves and analysis of antimicrobial activity. Int J Microbiol. 2019 Jul;2019:8642303.

[38] Chandhru M, Logesh R, Rani SK, Ahmed N, Vasimalai N. Onepot green route synthesis of silver nanoparticles from jack fruit seeds and their anti-bacterial activities with escherichia coli and salmonella bacteria. Biocatal Agric Biotechnol. 2019;20:101241.

[39] Al U, Mishra A, Jafri A, Arshad M, Siddiqui MA. Green synthesis of silver nanocomposites of nigella sativa seeds extract for hepatocellular carcinoma. Curr Nanomater. 2019;4(3):191-200.

[40] Masum MM, Siddiqa MM, Ali KA, Zhang Y, Abdallah Y, Ibrahim $\mathrm{E}$, et al. Biogenic synthesis of silver nanoparticles using phyllanthus emblicafruit extract and its inhibitory action against the pathogen acidovorax oryzaestrain RS-2 of rice bacterial brown stripe. Front Microbiol. 2019 Apr;10:820.

[41] Pirtarighat S, Ghannadnia M, Baghshahi S. Green synthesis of silver nanoparticles using the plant extract of Salvia spinosa grown in vitro and their anti-bacterial activity assessment. J Nanostructure Chem. 2019;9(1):1-9.

[42] Yousaf H, Mehmood A, Ahmad KS, Raffi M. Green synthesis of silver nanoparticles and their applications as an alternative antibacterial and antioxidant agents. Mater Sci Eng C. 2020 Jul;112:110901.

[43] Vasyliev G, Vorobyova V, Skiba M, Khrokalo L. Green Synthesis of Silver Nanoparticles Using Waste Products (Apricot and Black Currant Pomace). Adv Mater Sci Eng. 2020;2020:1-11.

[44] Sharifi-Rad M, Pohl P, Epifano F, Álvarez-Suarez JM. Green synthesis of silver nanoparticles using astragalus tribuloides delileRoot extract: Characterisation, antioxidant, anti-bacterial, and anti-inflammatory activities. Nanomaterials (Basel). 2020 Nov;10(12):1-17.

[45] Nilavukkarasi M, Vijayakumar S, Kumar SP. Biological synthesis and characterisation of silver nanoparticles with Capparis zeylanica L. leaf extract for potent antimicrobial and anti proliferation efficiency. Mater Sci Energy Technol. 2020;3:371-6.

[46] Doan VD, Huynh BA, Nguyen TD, Cao XT, Nguyen VC, Nguyen $\mathrm{TL}$, et al. Biosynthesis of Silver and Gold Nanoparticles Using Aqueous Extract of Codonopsis pilosula Roots for Antibacterial and Catalytic Applications. J Nanomater. 2020;2020:1-18.

[47] Kambale EK, Nkanga CI, Mutonkole BI, Bapolisi AM, Tassa DO, Liesse JI, et al. Green synthesis of antimicrobial silver nanopar- ticles using aqueous leaf extracts from three Congolese plant species (Brillantaisia patula, Crossopteryx febrifuga and Senna siamea). Heliyon. 2020 Aug;6(8):e04493.

[48] Hemlata, Meena PR, Singh AP, Tejavath KK. Biosynthesis of Silver Nanoparticles Using Cucumis prophetarum Aqueous Leaf Extract and Their Anti-bacterial and Antiproliferative Activity Against Cancer Cell Lines. ACS Omega. 2020;5:5520-8.

[49] Garibo D, Borbón-Nuñez HA, de León JN, García Mendoza E, Estrada I, Toledano-Magaña Y, et al. Green synthesis of silver nanoparticles using Lysiloma acapulcensis exhibit highantimicrobial activity. Sci Rep. 2020 Jul;10(1):12805.

[50] Chartarrayawadee W, Charoensin P, Saenma J, Rin T, Khamai $\mathrm{P}$, Nasomjai $\mathrm{P}$, et al. Green synthesis and stabilisation of silver nanoparticles using Lysimachia foenum-graecum Hance extract and their anti-bacterial activity. Green Process. Synth. 2020;9(1):107-18.

[51] Nikaeen G, Yousefinejad S, Rahmdel S, Samari F, Mahdavinia S. Central composite design for optimising the biosynthesis of silver nanoparticles using plantago major extract and investigating anti-bacterial, antifungal and antioxidant activity. Sci Rep. 2020 Jun;10(1):9642.

[52] Li S, Shen Y, Xie A, Yu X, Qiu L, Zhang L, et al. Green synthesis of silver nanoparticles using Capsicum annuum L. extract. Green Chem. 2007;9(8):852.

[53] Seifipour R, Nozari M, Pishkar L. Green synthesis of silver nanoparticles using tragopogon collinus leaf extract and study of their anti-bacterial effects. J Inorg Organomet Polym Mater. 2020;30(8):2926-36.

[54] Ahmed RH, Mustafa DE. Green synthesis of silver nanoparticles mediated by traditionally used medicinal plants in Sudan. Int Nano Lett. 2020;10(1):1-14.

[55] Begum Q, Kalam M, Kamal M, Mahboob T. Biosynthesis, Characterization, and Antibacterial Activity of Silver Nanoparticles Derived from Aloe barbadensis Miller Leaf Extract. Iran J Biotechnol. 2020 Apr;18(2):e2383.

[56] Bindhani BK, Panigrahi AK. Biosynthesis and Characterization of Silver Nanoparticles (Snps) by using Leaf Extracts of Ocimum Sanctum L (Tulsi) and Study of its Antibacterial Activities. J Nanomed Nanotechnol. 2015;6:1-5.

[57] Jain S, Mehata MS. Medicinal Plant leaf extract and pure flavonoid mediated green synthesis of silver nanoparticles and their enhanced anti-bacterial property. Sci Rep. 2017 Nov;7(1):15867.

[58] Singh J, Mehta A, Rawat M, Basu S. Green synthesis of silver nanoparticles using sun dried tulsi leaves and its catalytic application for 4-Nitrophenol reduction. J Environ Chem Eng. 2018;6(1):1468-74.

[59] Tailor G, Yadav BL, Chaudhary J, Joshi M, Suvalka C. Green synthesis of silver nanoparticles using Ocimum canum and their antibacterial activity. Biochem Biophys Rep. 2020 Dec;24:100848.

[60] Kamala NS, Vijayaraghavan K. Green synthesis of silver and gold nanoparticles using aloe vera gel and determining its antimicrobial properties on nanoparticle impregnated cotton fabric. J. Nanotechnol. Res. 2020;2(3):42-50.

[61] Selvaraj V, Sagadevan S, Muthukrishnan L, Johan MR, Podder J. Ecofriendly approach in synthesis of silver nanoparticles and evaluation of optical, surface morphological and antimicrobial properties. J Nanostructure Chem. 2019;9(2):153-62.

[62] GonzalezBallesteros N, RodriguezArguelles MC, LastraValdor M, GonzalezMediero G, ReyCao S, Grimaldi M, et al. Synthesis of sil- 
ver and gold nanoparticles by Sargassummuticum biomolecules and evaluation of their antioxidant activity and anti-bacterial properties. J Nanostructure Chem. 2020;10(4):317-30.

[63] Allafchian AR, Mirahmadi-Zare SZ, Jalali SA, Hashemi SS, Vahabi MR. Green synthesis of silver nanoparticles using phlomis leaf extractand investigation of their anti-bacterial activity. J Nanostructure Chem. 2016;6(2):129-35.

[64] Ahmadi O, Jafarizadeh-Malmiri H, Jodeiri N. Eco-friendly microwave-enhanced green synthesis of silver nanoparticles using Aloe vera leaf extract and their physico-chemical and antibacterial studies. Green Process. and Synth. 2018;7(3):231-40.

[65] Anju TR, Parvathy S, Veettil VM, Rosemary J, Ansalna TH, Shahzabanu MM, et al. Green synthesis of silver nanoparticles from Aloe vera leaf extract and its antimicrobial activity. Mater Today Proc. 2021;43:3956-60.

[66] Premkumar J, Sudhakar T, Dhakal A, Shrestha JB, Krishnakumar S, Balashanmugam P. Synthesis of silver nanoparticles (AgNPs) from cinnamon against bacterial pathogens. Biocatal Agric Biotechnol. 2018;15:311-6.

[67] Shao Y, Wu C, Wu T, Yuan C, Chen S, Ding T, et al. Green synthesis of sodium alginate-silver nanoparticles and their antibacterial activity. Int J Biol Macromol. 2018 May;111:1281-92.

[68] Yan X, He B, Liu L, Qu G, Shi J, Hu L, et al. Antibacterial mechanism of silver nanoparticles in Pseudomonas aeruginosa: proteomics approach. Metallomics. 2018 Apr;10(4):557-64.

[69] Gunalan S, Sivaraj R, Venckatesh R. Aloe barbadensis Miller mediated green synthesis of mono-disperse copper oxide nanoparticles: optical properties. Spectrochim Acta A Mol Biomol Spectrosc. 2012 Nov;97:1140-4.

[70] Medda S, Hajra A, Dey U, Bose P, Mondal NK. Biosynthesis of silver nanoparticles from Aloe vera leaf extractand antifungal activity against Rhizopus sp. and Aspergillus sp. Appl Nanosci. 2015;5(7):875-80.

[71] Ahmad N, Sharma S, Alam MK, Singh VN, Shamsi SF, Mehta BR, et al. Rapid synthesis of silver nanoparticles using dried medicinal plant of basil. Colloids Surf B Biointerfaces. 2010 Nov;81(1):81-6.

[72] Jeevanandam J, Chan YS, Danquah MK. Biosynthesis of metal and metal oxide nanoparticles. Chem. Bio. Eng. Rev. 2016;3(2):55-67.

[73] Sharma S, Kumar K, Thakur N, Chauhan S, Chauhan MS. Ecofriendly Ocimum tenuiflorum green route synthesis of $\mathrm{CuO}$ nanoparticles: characterisations on photocatalytic and antibacterial activities. J Environ Chem Eng. 2021;9(4):105395.

[74] Sharma S, Kumar K. Aloe-vera leaf extract as a green agent for the synthesis of $\mathrm{CuO}$ nanoparticles inactivating bacterial pathogens

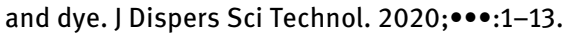

[75] Kumar S, Singh M, Halder D, Mitra A. Lippia javanica: a cheap natural source for the synthesis of anti-bacterial silver nanocolloid. Appl Nanosci. 2016;6(7):1001-7.

[76] Wani IA, Khatoon S, Ganguly A, Ahmed J, Ganguli AK, Ahmad T. Silver nanoparticles: large scale solvothermal synthesis and optical properties. Mater Res Bull. 2010;45(8):1033-8.

[77] Theivasanthi T, Alagar M. Electrolytic Synthesis and Characterization of Silver Nanopowder. Nano Biomed Eng. 2012;4(2):58-65.

[78] Edison TN, Lee YR, Sethuraman MG. Green synthesis of silver nanoparticles using Terminalia cuneata and its catalytic action in reduction of direct yellow-12 dye. Spectrochim Acta A Mol Biomol Spectrosc. 2016 May;161:122-9.

[79] Yang H, Ren Y, Wang T, Wang C. Preparation and anti-bacterial activities of $\mathrm{Ag} / \mathrm{Ag}^{+} / \mathrm{Ag}_{3}^{+}$nanoparticle composites made by pomegranate (Punica granatum) rind extract. Results Phys.
2016;6:299-304.

[80] Ghozali S, Vuanghao L, Ahmad N. Biosynthesis and Characterization of Silver Nanoparticles using Catharanthus roseus Leaf Extract and its Proliferative Effects on Cancer Cell Lines. J Nanomed Nanotechnol. 2015;6(4):1-6.

[81] Logaranjan K, Raiza AJ, Gopinath SC, Chen Y, Pandian K. Shape and size-controlled synthesis of silver nanoparticles using aloe vera plant extract and their antimicrobial activity. Nanoscale Res Lett. 2016 Dec;11(1):520.

[82] Brahmachari G, Sarkar S, Ghosh R, Barman S, Mandal NC, Jash SK, et al. Sunlight-induced rapid and efficient biogenic synthesis of silver nanoparticles using aqueous leaf extract of Ocimum sanctum Linn. with enhanced antibacterial activity. Org Med Chem Lett. 2014 Dec;4(1):18.

[83] Lopez Z, Nunez-Jinez G, Avalos-Navarro G, Rivera G, SalazarFlores J, Ramirez JA, et al. Antioxidant and cytotoxicological effects of Aloe vera food supplements. J Food Qual. 2017;2017:110.

[84] Hashemi SA, Madani SA, Abediankenari S. The review on properties of aloe vera in healing of cutaneous wounds. BioMed Res Int. 2015;2015:714216.

[85] Kulkarni VD, Kulkarni PS. Green synthesis of copper nanoparticles using ocimum. Int J Chem Stud. 2013;1:1-4.

[86] Anandalakshmi K, Venugobal J, Ramasamy V. Characterization of silver nanoparticles by green synthesis method using Pedalium murex leaf extract and their anti-bacterial activity. Appl Nanosci. 2016;6(3):399-408.

[87] Chauhan R, Reddy A, Abraham J. Biosynthesis of silver and zinc oxide nanoparticles using Pichia fermentans JA2 and their antimicrobial property. Appl Nanosci. 2015;5(1):63-71.

[88] Vithiya K, Kumar R, Sen S. Antimicrobial Activity of Biosynthesized Silver Nanoparticles. J Pure Appl Microbiol. 2014;8:32638.

[89] Dharmaraj D, Krishnamoorthy M, Rajendran K, Karuppiah K, Annamalai J, Durairaj KR, et al. Antibacterial and cytotoxicity activities of biosynthesised silver oxide $\left(\mathrm{Ag}_{2} \mathrm{O}\right)$ nanoparticles using Bacillus paramycoides. J Drug Deliv Sci Technol. 2021;61:102111.

[90] Jiang H, Zhang G, Xu B, Feng X, Bai Q, Yang G, et al. Thermosensitive anti-bacterial $\mathrm{Ag}$ nanocomposite hydrogels made by a onestep green synthesis strategy. New J Chem. 2016;40(8):6650-7.

[91] Wang L, Hu C, Shao L. The antimicrobial activity of nanoparticles: present situation and prospects for the future. Int J Nanomedicine. 2017 Feb;12:1227-49.

[92] Mahlaule-Glory LM, Mbita Z, Mathipa MM, Tetana ZN, HintshoMbita NC. Biological therapeutics of AgO nanoparticles against pathogenic bacteria and A549 lung cancer cells. Mater Res Express. 2019;6(10):105402.

[93] Pazos-Ortiz E, Roque-Ruiz JH, Hinojos-Marquez EA, LopezEsparza J, Donohue-Cornejo A, Cuevas-Gonzalez JC, et al. DoseDependent Antimicrobial Activity of Silver Nanoparticles on Polycaprolactone Fibers against Gram-Positive and Gram-Negative Bacteria. J Nanomater. 2017;2017:1-9.

[94] Al-Sharqi A, Apun K, Vincent M, Kanakaraju D, Bilung LM. Enhancement of the Anti-bacterial Efficiency of Silver Nanoparticles against Gram-Positive and Gram-Negative Bacteria Using Blue Laser Light. Int J Photoenergy. 2019;2019:1-12.

[95] Gao Y, Wang X, Li X, Dai H. An anti-bacterial composite film based on cellulose acetate $/ \mathrm{TiO}_{2}$ nanoparticles. New J Chem. 2020;44(47):20751-8. 
[96] Gabrielyan L, Badalyan H, Gevorgyan V, Trchounian A. Comparable antibacterial effects and action mechanisms of silver and iron oxide nanoparticles on Escherichia coli and Salmonella typhimurium. Sci Rep. 2020 Aug;10(1):13145.

[97] Rout Y, Behera S, Ojha AK, Nayak LP. Green synthesis of silver nanoparticles using Ocimum sanctum (Tulashi) and study of their anti-bacterial and antifungal activities. J Microbiol Antimicrob. 2012;4(6):103-9.
[98] Wypij M, Czarnecka J, Świecimska M, Dahm H, Rai M, Golinska P. Synthesis, characterization and evaluation of antimicrobial and cytotoxic activities of biogenic silver nanoparticles synthesized from Streptomyces xinghaiensis OF1 strain. World J Microbiol Biotechnol. 2018 Jan;34(2):23.

[99] Yadav J, Kumar S, Yadav A, Yadav M. Characterization and antibacterial activity of synthesized silver and iron nanoparticles using aloe vera. J Nanomed Nanotechnol. 2016;7(3):1-7. 